\title{
STRATEGI ADAPTASI BANGUNAN DI PERUMNAS CONDONG CATUR SLEMAN DAERAH ISTIMEWA YOGYAKARTA
}

\author{
Dita Ayu Rani Natalia ${ }^{1, *}$, M. Sani Roychansyah ${ }^{2}$ \\ ${ }^{1}$ Arsitektur, Fakultas Sains dan Teknologi, Universitas Teknologi Yogyakarta, \\ Jl. Glagahsari No.63 Yogyakarta, 55164 \\ ${ }^{2}$ Arsitektur, Fakultas Arsitektur dan Perencanaan, Universitas Gadjah Mada, \\ Jl. Grafika No.2 Yogyakarta, 55281 \\ *ditayurani@gmail.com
}

\begin{abstract}
ABSTRAK. Bangunan merupakan benda yang bergerak dinamis dan akan mengalami perubahan dalam kurun waktu tertentu. Perubahan bangunan yang dilakukan untuk dapat digunakan secara maksimal disebut dengan adaptasi bangunan. Adaptasi bangunan adalah "pekerjaan pada bangunan untuk pemeliharaan dalam mengubah kapasitas, fungsi dan performance dengan kata lain melakukan intervensi untuk menyesuaikan, menggunakan ulang dan meningkatkan kemampuan bangunan". Cara yang dapat digunakan oleh penghuni atau pemilik ketika bangunan sudah tidak lagi bekerja secara optimal adalah dengan membiarkan, melakukan perubahan atau menghancurkannya. Hal tersebut dilakukan dengan beberapa strategi yang digunakan dalam adaptasi bangunan. Tujuan penelitian yaitu mengidentifikasi strategi adaptasi bangunan yang digunakan dan terjadi di Perumnas Condongcatur. Metode penelitian yang digunakan dalam penelitian ini adalah deduktif kualitatif dengan teknik pengambilan sampel menggunakan purposive sampling yang bertujuan untuk mengumpulkan data secara spesifik. Pengumpulan data dilakukan dengan melakukan observasi yang terdiri dari pengamatan, kuisioner, interview dan dokumentasi. Data yang telah terkumpul kemudian di analisa berdasarkan perubahan fisik bangunan yang kemudian di diskusikan dengan teori dalam diskusi temuan. Hasil penelitian yang telah dilakukan bahwa terdapat enam strategi adaptasi bangunan di Perumnas Condongcatur. Strategi tersebut antara lain perubahan perabotan (adjustable), perubahan tatanan ruang (versatile), perubahan performance (refitable), perubahan fungsi (convertible), perubahan ukuran (scalable) dan perubahan tatanan layout perabotan.
\end{abstract}

Kata kunci:Strategi, Adaptasi Bangunan, Perumnas

ABSTRACT. Building is a dynamic object and keeps changing in particular period of time. Any change in order to take maximum advantage of the building is called building adaptation. Building adaptation is "any work to a building over and above maintenance to change its capacity, function, or performance' in other words, 'any intervention to adjust, reuse, or upgrade a building." When a building does not function as it is supposed to be, the owner can abandon, change, or destroy it. These are carried out by employing several strategies of building adaptation. This research is aimed to identify strategy of building adaptation used and occurred in Perumnas Condong Catur. Deductive qualitative research method was employed in this research with the samples were taken applying purposive sampling technique which was aimed to specify the collecting of the data. Data collecting was conducted by observation including observation, questionnaires, interview, and documentation. The collected data were analyzed according physical changes of the houses and the analysis were then discussed in the research finding using the theory. The results of the research show that there are six strategies in the building adaptation of Perumnas Condongcatur. They are change of the furniture (adjustable), change of the layout (versatile), change of the performance (refitable), change of the function (convertible), change of the size (scalable), and change of the furniture layout.

Keywords: Strategy, Building Adaptation, Perumnas

\section{PENDAHULUAN}

Bangunan sebagai kebutuhan manusia menjadi salah satu hal yang penting dalam melihat perkembangan yang terjadi. Bangunan merupakan benda yang bergerak dinamis dan akan mengalami perubahan dalam kurun waktu tertentu. Perubahan bangunan agara dapat digunakan secara maksimal disebut dengan adaptasi bangunan. Schmidt, dkk [1] mendefinisikan adaptasi bangunan sebagai "kapasitas bangunan untuk menampung secara efektif untuk mengakomodasi tuntutan yang berkembang dari konteks, sehingga memaksimalkan nilai melalui kehidupan". Bangunan yang mengalami adaptasi dipengaruhi oleh adanya faktor-faktor yang mempengaruhi seperti fungsi bangunan yang sudah tidak sesuai, kualitas bangunan yang menurun karena adanya faktor usia dan faktor 
lain termasuk adanya keinginan pengguna. Hal tersebut dilakukan dengan beberapa strategi adaptasi bangunan yang terdiri dari adjustable, versatile, refitable, convertible, scalable dan movable.

Siklus bangunan dipengaruhi oleh periode waktu karena dapat merekam adaptasi bangunan yang terjadi. Usia bangunan yang lama dapat mempengaruhi pemilik atau pengguna untuk memaksimalkan bangunan dengan adanya perubahan dan penyesuaian dalam meningkatkan kapasitas dan kebutuhan. Pemilihan lokasi penelitian mempertimbangkan usia bangunan yang lebih dari 30 tahun dan mengalami perubahan dari periode awal sampai sekarang. Lokasi penelitian adaptasi bangunan dilakukan di Perumnas Condongcatur yang merupakan perumahan pertama di Yogyakarta. Pemilihan Perumnas Condongcatur karena mempunyai homogenitas bangunan serta perubahan fisik bangunan yang signifikan semenjak dibangun pada tahun 1978-1979.

Bangunan dalam kurun waktu yang lama akan mengalami penurunan, sehingga tidak dapat bekerja secara optimal. Permasalahan tersebut dapat diatasi dengan melakukan perubahan melalui adaptasi bangunan. Berdasarkan permasalahan penelitian tersebut maka dapat ditarik pertanyaan penelitian, yaitu strategi apakah yang digunakan dalam adaptasi bangunan di Perumnas Condongcatur. Tujuan penelitian ini adalah mengidentifikasi strategi adaptasi bangunan yang digunakan di Perumnas Condongcatur.

\section{Adaptasi Bangunan}

Adaptasi bangunan merupakan pekerjaan pada bangunan karena tidak terpenuhinya basic bangunan sehingga bangunan kurang optimal atau mengalami kerusakan sehingga terjadi keusangan karena usia bangunan. Bangunan yang mengalami adaptasi dapat mencakup pekerjaan renovasi, adaptive reuse, perbaikan, remodelling, pemulihan, perkuatan, konversi, transformasi, rehabilitasi, modernisasi, re-lifting, restorasi dan bangunan daur ulang. Schmidt, dkk [1] mendefinisikan adaptasi bangunan sebagai "kapasitas bangunan untuk menampung secara efektif untuk mengakomodasi tuntutan yang berkembang dari konteks, sehingga memaksimalkan nilai melalui kehidupan".

Dalam prespektif waktu, bangunan mengalami penurunan performance secara fungsi maupun elemen-elemen arsitekturnya. Bangunan tidak hanya sebagai obyek yang diam tetapi menjadi obyek yang bergerak secara dinamis dengan adanya pergeseran dalam lingkungan. Waktu dalam adaptasi melihat ruang, fungsi dan komponen secara keseluruhan sehingga bangunan dapat digunakan secara maksimal.

Bangunan yang mengalami adaptasi dipengaruhi oleh adanya faktor-faktor yang mempengaruhi seperti adanya fungsi bangunan yang sudah tidak sesuai, kualitas bangunan yang menurun karena adanya faktor usia (usang) dan faktor lain termasuk adanya keinginan pengguna. Schmidt, dkk [2] menyatakan bahwa "adaptasi sebagai karakteristik desain merupakan perwujudan tatanan, struktur dan stategi layanan yang memungkinkan tingkatan obyek fisik dalam menangapi perubahan parameter dari waktu ke waktu".

Adaptasi bangunan mengakibatkan adanya perubahan fungsi, kapasitas dan performance bangunan sehingga bangunan tersebut dapat digunakan secara optimal. Menurut Schmidt [2] terdapat enam strategi adaptasi bangunan, yaitu adjustable (perubahaan perabotan atau furnitur), versatile (perubahan tatanan ruang), refitable (perubahan performance komponen), convertible (perubahan fungsi), scalable (perubahan ukuran) dan movable (perubahan lokasi).

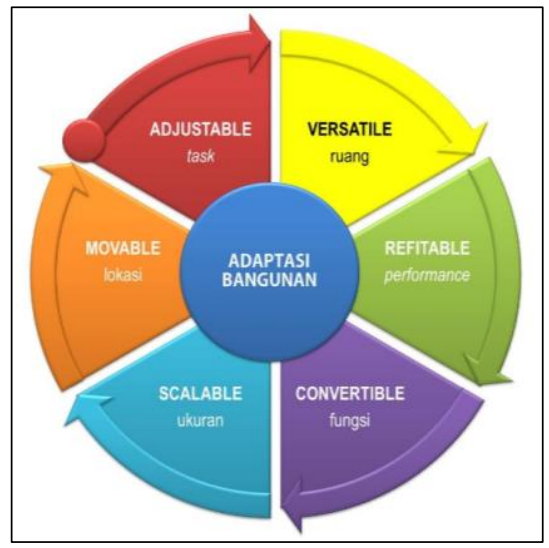

\section{Gambar 1. Strategi Adaptasi Bangunan} (Sumber: [3])

Adjustable merupakan perubahan peralatan atau furnitur karena menyesuaikan dengan keinginan pengguna atau pemilik. Strategi versatile merupakan perubahan tatanan fisik ruang yang dipengaruhi oleh adanya komponen dan perabotan yang ada. Refitable berkaitan dengan adanya perubahan komponen yang mempengaruhi elemen arsitektur bangunan. Strategi convertible merupakan perubahan yang diakibatkan 


\begin{tabular}{|c|c|c|c|c|c|c|c|c|c|c|}
\hline \multicolumn{3}{|c|}{ Tipe Perubahan } & \multicolumn{6}{|c|}{ Brand's Layer } & \multicolumn{2}{|c|}{ Skala } \\
\hline Strategi & $\begin{array}{c}\text { Sosial } \\
\text { (penyebab) }\end{array}$ & $\begin{array}{c}\text { Fisik } \\
\text { (akibat) }\end{array}$ & $\begin{array}{l}\text { Barang } \\
\text { (stuff) }\end{array}$ & $\begin{array}{l}\text { Ruang } \\
\text { (space) }\end{array}$ & Service & $\begin{array}{l}\text { Kulit } \\
\text { (Skin) }\end{array}$ & Struktur & Site & Fisik & Waktu \\
\hline Adjustable & $\begin{array}{l}\text { Task, } \\
\text { penggguna }\end{array}$ & $\begin{array}{l}\text { Peralatan, } \\
\text { furnitur }\end{array}$ & & & & & & & Komponen & harian/bulanan \\
\hline Versatile & $\begin{array}{l}\text { Pedagogy, } \\
\text { operator }\end{array}$ & $\begin{array}{l}\text { Tatanan } \\
\text { spasial }\end{array}$ & & & & & & & Komponen & harian/bulanan \\
\hline Refitable & $\begin{array}{l}\text { Usia, } \\
\text { teknologi, } \\
\text { kebijakan }\end{array}$ & $\begin{array}{l}\text { Komponen } \\
\text {, kinerja }\end{array}$ & & & & & & & Komponen & 7 tahun \\
\hline Convertible & Pemilik & Fungsi & & & & & & & Bangunan & 15 tahun \\
\hline Scalable & $\begin{array}{l}\text { company, } \\
\text { pasar }\end{array}$ & $\begin{array}{l}\text { Ukuran, } \\
\text { beban }\end{array}$ & & & & & & & Bangunan & 15 tahun \\
\hline Movable & $\begin{array}{l}\text { Lingkungan, } \\
\text { demografi }\end{array}$ & lokasi & & & & & & & Bangunan & 30 tahun \\
\hline & & & & & KEY & $\mathrm{Pr}$ & 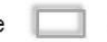 & ssible & & \\
\hline
\end{tabular}

Gambar 2. Strategi Adaptasi Bangunan Schmidt [2] dan Brand's Layers (Sumber: [3])

karena adanya fungsi tambahan ataupun perluasan ruang. Strategi scalable merupakan adaptasi bangunan yang berkaitan dengan adanya konstruksi penambahan struktur dalam memenuhi kebutuhan pengguna atau pemilik. Strategi yang terakhir yaitu movable yang merupakan adanya perpidahan lokasi bangunan karena bangunan tidak dapat lagi memenuhi kebutuhan penghuni maupun pemilik.

Strategi adaptasi berkaitan dengan waktu dan usia bangunan, seperti yang dikemukan oleh Brands [4] tentang shearing layers yang kemudian dikembangkan oleh Schmidt [2] Shearing layers yang dikemukakan oleh Brands terdiri dari lapisan stuff, space plan, services, skin, structure dan site. Lapisan tersebut oleh Schmidt kemudian dikembangkan dengan tipe perubahan yang terdiri dari strategi, sosial berhubungan dengan penyebab perubahan dan fisik yang berkaitan dengan akibat perubahan.

\section{Perumnas}

Rumah merupakan salah satu kebutuhan pokok bagi kehidupan manusia. Semakin bertambahnya jumlah penduduk maka semakin besar pula kebutuhan rumah yang menyebabkan harga lahan dan permukiman semakin tinggi. Atas dasar tersebut maka pemerintah mendirikan perusahan Perumnas yang bertujuan untuk menyediakan perumahan yang layak bagi masyarakat menengah ke bawah. Pembangunan perumahan di Indonesia diawali pada masa pemerintahan Hindia Belanda. Pada masa tersebut pengadaan perumahan di Indonesia diatur oleh lembaga yang bernama Van Verkeer en Waterstaat. Modal pembangunan perumahan berasal dari modal pemerintah pusat sebesar $25 \%$ dan pemerintah daerah (Gemeente) sebesar 75\% [5]. Peralihan kekuasaan dari Hindia Belanda ke Jepang mempengaruhi penggantian nama lembaga menjadi Doboku. Pasca kemerdekaan kemudian pengembangan perumahan dilaksanakan oleh Departemen Pekerjaan Umum [6].

Perumnas merupakan badan milik pemerintah yang menanggani pembangunan perumahan dalam skala besar. Menurut Perumnas [7] konsep pengembangan skala besar dalam perumahan membuat Perumnas berhasil memberikan konstribusi signifikan dalam pembentukan kawasan permukiman dan kotakota baru yang tersebar di seluruh Indonesia.

Perumahan yang dibangun oleh Perumnas antara lain Rumah Sederhana Sehat (RSH), Rumah Sederhana (RS) dan Rumah Menengah (RM). Perumnas sebagai pengembang perumahan dan permukiman terpercaya di Indonesia mempunyai tujuan yaitu sebagai penyedia dan pengembang perumahan untuk masyarakat menengah ke bawah. 
Produk perumahan yang dikembangkan oleh Perumnas merupakan perumahan masal yang mempunyai tipe seragam. Berdasarkan website Perumnas tipe rumah yang dibangun merupakan tipe rumah sederhana dengan luasan tipe 29 dan 36 dengan luas tanah minimal $90 \mathrm{~m} 2$. Secara umum karakteristik perumahan yang dikembangkan oleh Perumnas, antara lain: 1) Perumahan dengan skala masal; 2) Luas tipe rumah seragam; 3) Perumahan untuk masyarakat menengah ke bawah; 4) Tersedianya sarana dan prasarana perumahan yang dikembangkan bersama pemerintah; 5) Pengembangan perumahan dengan luas lahan yang besar dan merupakan lahan pemerintah atau BUMN.

\section{METODE PENELITIAN}

Metoda yang digunakan pada penelitian ini adalah metoda deduktif kualitatif dengan mengacu kepada teori adaptasi bangunan. Variabel pada penelitian ini berdasarkan strategi adaptasi bangunan yaitu adjustable, versatile, refitable, convertible dan scalable.

Teknik pengambilan sampel/ responden yang digunakan adalah purposive sampling. Langkah awal dalam pengambilan sampel berdasarkan data sekunder yang diperoleh dari dari Kantor Perumnas dan instansi terkait. Data yang telah diperoleh kemudian menjadi dasar dalam pengambilan sampel dengan melakukan identifikasi populasi melalui klasifikasi perubahan. Klasifikasi identifikasi bangunan meliputi perubahan (ringan, sedang dan total) dan fungsi bangunan. Identifikasi klasifikasi bangunan kemudian menjadi parameter dalam penentuan sampel bangunan yang digunakan dalam penelitian.

Data primer dan sekunder yang telah terkumpul kemudian di analisa dalam beberapa tahap, antara lain:

1. Data hasil observasi dan pengamatan masing-masing bangunan dibuat periode dalam waktu perubahan

2. Hasil data tersebut kemudian dilengkapi dengan data kuisioner dan interview sehingga dapat mengetahui perubahan pada bangunan.

Hasil data keseluruhan kemudian dibuat tabel yang berkaitan dengan periode perubahan yang kemudian dikaitkan dengan strategi adaptasi.Hasil temuan di lapangan kemudian di analisa perubahan fisik bangunan yang telah dilakukan dan alasan melakukan perubahan tersebut. Hasil analisa kemudian di diskusikan dengan teori yang telah ada dalam pembahasan dan diskusi temuan.

\section{HASIL DAN PEMBAHASAN}

\section{Lokasi Penelitian}

Lokasi penelitian berada di Perumnas Condongcatur yang secara administrasi terletak di Kecamatan Depok, Kelurahan Condongcatur, Kabupaten Sleman. Kawasan Perumnas terbagi menjadi 3 Rukun Warga, yaitu RW 13 (dusun Gempol), RW 17 (dusun Dero dan RW 22 (dusun Ngringin).

Perumnas Condongcatur merupakan Perumnas pertama di Indonesia yang dibangun pada tahun 1978-1979 dan sebagai pilot project untuk pengembangan perumahan rakyat. Pembangunan perumnas ini diperuntukan untuk Pegawai Negeri Sipil (PNS) golongan $1 / I / / I I$ dan pegawai BUMN yang belum mempunyai rumah. Tipe rumah Perumnas yang dikembangkan dengan luasan $36 \mathrm{~m} 2$ dan luas tanah $96 \mathrm{~m} 2$. Menurut responden Ketua RW 17 selama 2 tahun kepemilikan, rumah tidak boleh disewakan

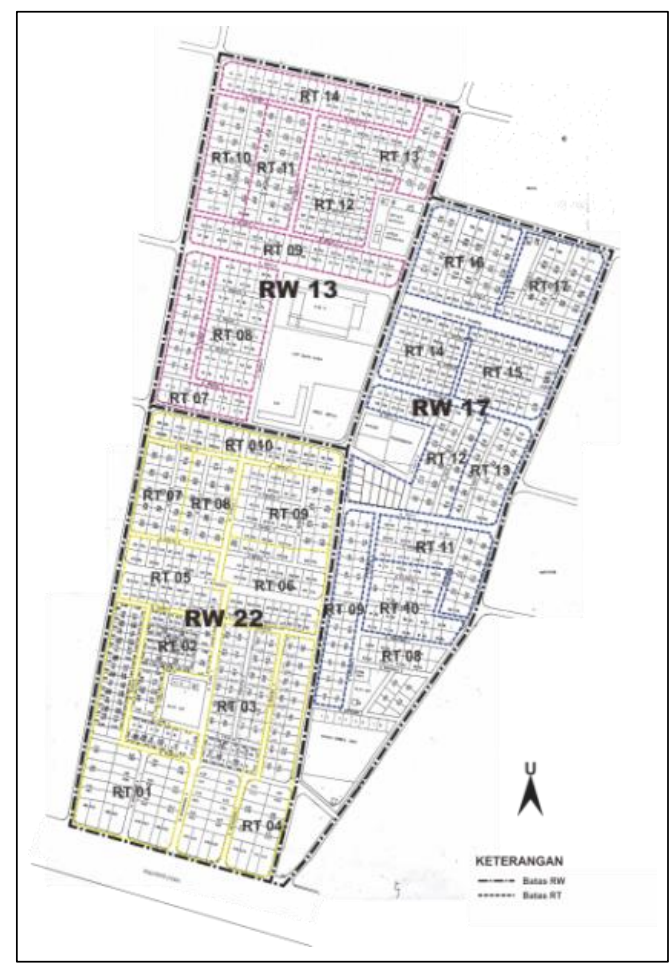

atau diperjualbelikan kepada pihak lain.

Gambar 3. Lokasi Penelitian di Perumnas Condong Catur

(Sumber: Observasi Lapangan, 2015)

Pada saat ini kepemilikan rumah di Perumnas Condong Catur sudah banyak berpindah 
tangan dan beralih fungsi, terutama di RW 17. Bangunan pada wilayah tersebut sebagai besar merupakan pendatang yang kemudian melakukan perubahan dan perbaikan pada bangunan asli Perumnas.

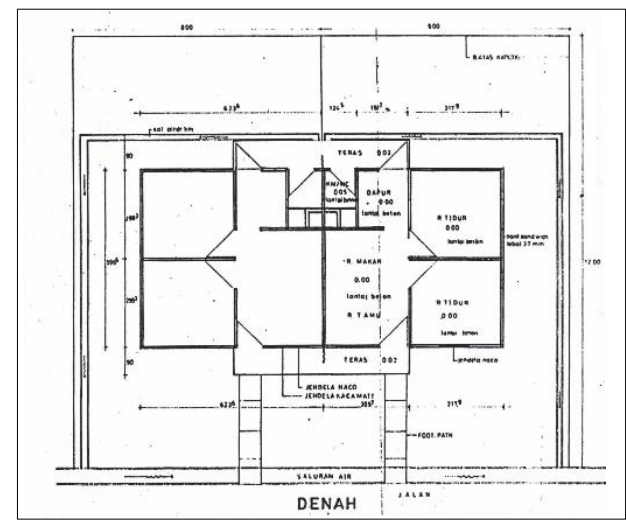

Gambar 4. Denah Awal Rumah di Perumnas Condong Catur

(Sumber: Observasi Lapangan, 2015)

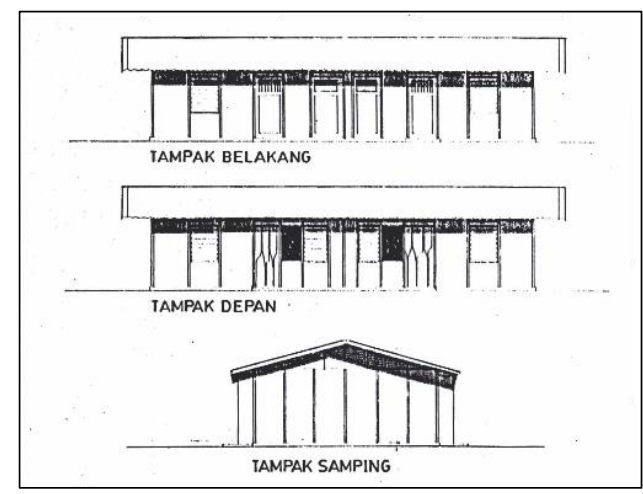

Gambar 5. Tampak Awal Rumah di Perumnas Condong Catur

(Sumber: Observasi Lapangan, 2015)

\section{Perkembangan dan Perubahan Fisik Kawasan}

Pembangunan fasilitas pendidikan seperti Universitas, fasilitas pendidikan dan fasilitas ekonomi menyebabkan kawasan Condongcatur berkembangan sangat pesat. Hal tersebut menyebabkan adanya perubahan fisik dan spasial bangunan termasuk Perumnas Condongcatur. Perumahan yang pada awalnya terletak di daerah pinggiran perkotaan kemudian menjadi kawasan yang strategis dengan adanya pembangunan infrastruktur jalan dan pengembangan fasilitas umum maupun komersial.

Perubahan makro kawasan menyebabkan adanya perubahan pada bangunan dengan adanya penyesuaian fungsi dan kebutuhan penghuni. Perubahan yang dilakukan antara lain melakukan perbaikan, perluasan, penambahan, penggantian fungsi ataupun dengan melakukan perubahan secara total. Menurut data hasil survey lapangan tahun 2015 dari total 1249 bangunan, perubahan total memiliki prosentase tertinggi sebesar $44,33 \%$ dan prosentase terendah pada perubahan ringan sebesar $15,77 \%$, sedangkan perubah sedang memiliki prosentase $40,14 \%$. Perubahan bangunan tersebut memiliki sebaran yang merata pada tiap RW dengan dominasi perubahan paling terdapat di RW 22 sebanyak 475 unit bangunan.

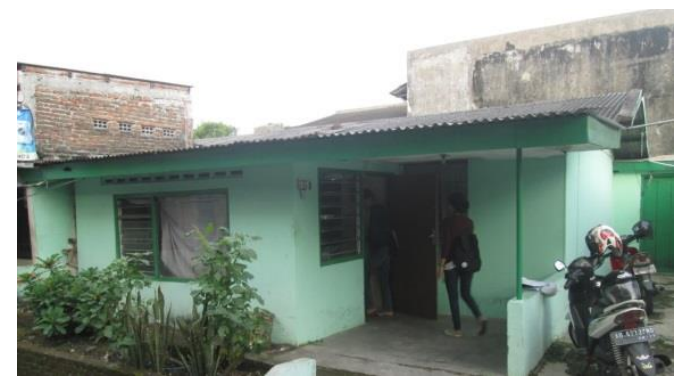

Gambar 6. Perubahan Ringan (Sumber: Observasi Lapangan, 2015)

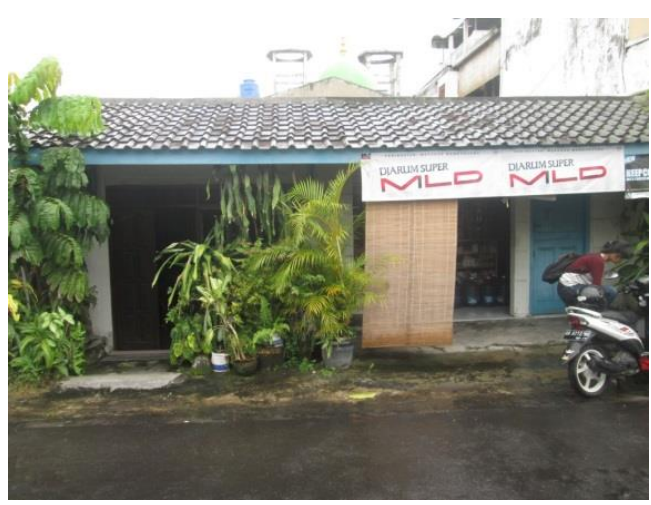

Gambar 7. Perubahan Sedang (Sumber: Observasi Lapangan, 2015)

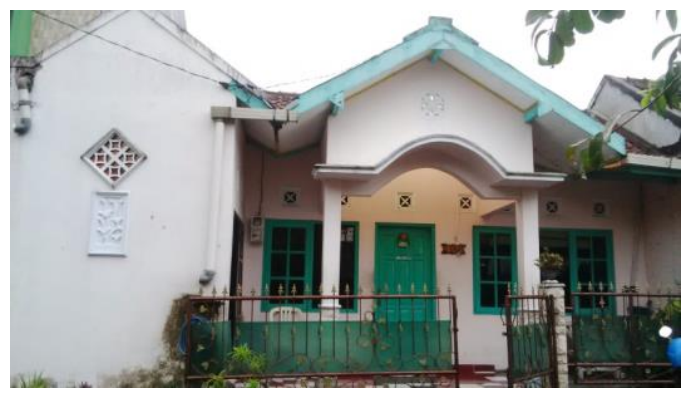

Gambar 8. Perubahan Total

(Sumber: Observasi Lapangan, 2015)

Menurut data Perum Perumnas tahun 1978 terdapat 1213 unit rumah dan 16 kios dengan 
adanya penambahan 20 unit rumah pada tahun 2014. Berdasarkan hasil survey 2015 bahwa unit rumah di Perumnas mengalami perubahan fungsi lain sebanyak 196 unit bangunan dengan fungsi dominan berupa jasa. Persebaran fungsi usaha perdagangan terdapat pada area yang berdekatan dengan jalan utama, sedangkan pada gang tidak banyak mengalami perubahan selain dalam skala pelayanan kecil (toko kelontong). Berdasarkan hasil observasi lapangan terdapat 86 unit bangunan yang mengalami perubahan fungsi sebagai tempat usaha perdagangan, selanjutnya 57 unit jasa yang terdiri dari laundry, fotokopi, bengkel dan lain sebagainya yang merupakan pendukung kawasan.

\section{Strategi Adaptasi Bangunan}

Adaptasi bangunan merupakan perubahan atau penambahan pada bangunan agar dapat digunakan secara maksimal dan optimal. Adaptasi bangunan dilakukan pada skala perubahan yang kecil yang berkaitan dengan perabotan dan skala perubahan besar pada bangunan. Pada hasil temuan terdapat beberapa perubahan yang dilakukan oleh pemilik atau pengguna bangunan, yaitu:

\section{Penataan ulang layout perabotan akibat penambahan, pemindahan dan perluasan ruang.}

Penataan ulang layout perabotan yang dilakukan oleh penghuni ataupun pemilik berdasarkan data hasil lapangan bahwa sebagian besar dilakukan ketika terjadi penambahan, pemindahan atapun perluasan ruang dari bangunan inti. Pada sampel bangunan perubahan layout ruang terjadi karena adanya perubahan letak dapur yang pada awalnya berdekatan dengan kamar mandi kemudian dipindahkan ke belakang dengan memanfaatkan lahan sisa sehingga layout perabotan akan berbeda. Sampel yang lain adalah pembongkaran ruang kamar mandi yang kemudian dipindahkan ke lahan sisa, maka ruang mengalami perluasan sehingga penataan layout akan berubah. Perubahan ini terjadi pada periode waktu ketika penambahan, pemindahan dan perluasan ruang berlangsung.

\section{Penataan ulang layout akibat penambahan perabotan baru.}

Perubahan layout ruang selain perluasan ataupun penambahan ruang juga karena adanya penambahan perabotan atau furniture baru. Penambahan perabotan karena kebutuhan pengguna akibat bertambahnya anggota keluarga maupun dalam satu rumah terdapat beberapa keluarga maka akan menambah perabotan yang ada. Perabotan yang lama akan tetap digunakan sehingga pembelian perabotan baru akan menyesuaikan dengan penataan layout ruang yang ada. Pembelian perabotan yang baru karena perabotan lama telah rusak pada beberapa sampel tidak mempengaruhi perubahan layout secara keseluruhan terutama perabotan elektronik yang secara umum hanya menggantikan tempat barang lama. Perabotan almari maupun meja kursi yang lama dan digantikan dengan yang baru sehingga tidak mempengaruhi layout yang ada. Perabotan tersebut melengkapi perabotan yang ada karena berhubungan dengan masalah sosial ataupun komunitas bagi pemilik maupun penghuni yang sering mengadakan acara keluarga maupun komunitas.

\section{Penataan ulang layout ruang untuk kegiatan komunitas sosial dan keluarga.}

Tatanan spasial dipengaruhi oleh penggunaan ruang yang digunakan secara multifungsi karena adanya penggunaan komponen ruang mempengaruhi tampilan dan tatanan ruang. Hal ini dapat ditemukan pada ruang yang menggunakan ruang yang dapat digunakan secara bersama.Kegiatan sosial masyarakat seperti arisan dasawisma, ibu-ibu, PKK dan acara lain menggunakan rumah warga di Perumnas Condongcatur sebagai tempat berkumpul. Rumah yang digunakan sebagai tempat berkumpul berdasarkan kesepakatan warga untuk gilirannya. Penggunaan rumah sebagai tempat berkumpul secara sosial masyarakat maupun tempat berkumpul keluarga apabila ada acara keagamaan maupun arisan keluarga menggunakan ruang yang terdapat di dalam rumah. Penggunaan ruang tersebut memberikan dampak pada tatanan pada ruang yang akan digunakan.

\section{Perubahan komponen bangunan.}

Perubahan penggunaan komponen pada bangunan mempengaruhi bentuk ruang sehingga dapat memberikan tampilan yang berbeda. Penggunaan komponen yang dapat dipindahkan secara mudah dengan di geser maupun yang bersifat movable. Komponen yang dapat dirubah sesuai dengan kebutuhan pemilik atau pengguna dengan jangka waktu yang lama. Komponen dalam rumah dapat digunakan secara optimal dan ruang dapat digunakan sesuai dengan kebutuhan dan 
fungsi pemilik atau penggunanya. Kegiatan yang dilakukan oleh pemilik rumah membutuhkan komponen dalam rumah yang dapat digunakan secara fleksibel dan dipindahkan dengan mudah. Perubahan dan penggunaan komponen bangunan di Perumnas Condong Catur yaitu penggunaan pintu lipat yang dapat difungsikan sebagai pemisah dan memberikan tampilan yang berbeda pada fungsi ruang.

\section{Perubahan dan/atau penambahan fungsi bangunan.}

Perubahan fungsi bangunan disebabkan karena adanya keinginan pemilik atau pengguna agar dapat digunakan secara optimal dan maksimal. Bangunan yang pada awalnya merupakan tempat tinggal kemudian bertambah atau berubah dengan fungsi perdagangan dan jasa dengan membuka warung maupun usaha yang lain. Perubahan fungsi tersebut mempengaruhi penggunaan ruang yang pada awalnya ruang tamu kemudian berubah menjadi ruang usaha atau toko Rumah di Perumnas Condongcatur dari 45 sampel terdapat 13 sampel yang mempunyai perubahan fungsi selain tempat tinggal.

\section{Penggunaan ruang bersama untuk acara komunitas dan keluarga.}

Perubahan ruang bersama merupakan penggunaan ruang yang dapat digunakan secara bersama, seperti ruang tamu sekaligus ruang keluarga. Penggunaan ruang bersama terjadi di 31 sampel dari 45 sampel yang diteliti.

Berdasarkan data tersebut, ruang bersama yang paling banyak digunakan untuk acara adalah ruang tamu dan keluarga. Penggunaan ruang bersama tersebut karena ketersedian ruang tamu dan keluarga yang berdekatan. Sarana dan komponen yang terdapat diruang tersebut menjadi pemisah antara ruang tamu dan keluarga.

\section{Perubahan dan/atau penambahan fungsi dan ukuran ruang.}

Pembangunan ruang baru pada bangunan juga menyebabkan adanya perubahan fungsi ruang. Pada sampel yang banyak ditemukan adalah perubahan dan pemindahan letak kamar mandi dan dapur. Letak kamar mandi yang berdekatan dengan dapur sebagian besar pada sampel dipindahkan ke belakang dengan memanfaatkan sisa tanah yang ada. Fungsi awal yang merupakan ruang servis (kamar mandi dan dapur) berubah fungsi menjadi ruang semi privat, seperti ruang makan, ruang setrika dan gudang. Perubahan fungsi yang lain adalah penggunaan ruang yang awalnya merupakan ruang privat, seperti kamar tidur menjadi ruang semi privat (ruang keluarga).

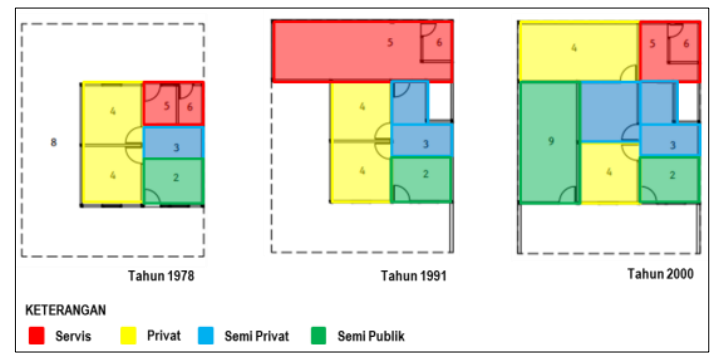

Gambar 9. Perubahan dan/atau Penambahan Fungsi Ruang Servis dan Semi Publik (Sumber: Observasi Lapangan, 2015)

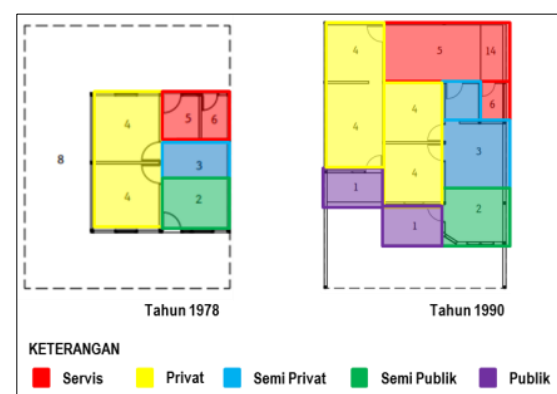

Gambar 10. Perubahan dan/atau Penambahan Fungsi Ruang Privat dan Publik (Sumber: Observasi Lapangan, 2015)

Pada gambar 10 sampel bangunan di Perumnas terdapat penambahan ruang publik pada bagian depan yang berfungsi sebagai ruang tamu. Penambahan fungsi ruang juga terdapat pada bagian samping dan belakang bangunan. Pada bagian belakang terdapat penambahan ruang servis (dapur dan ruang jemur), sedangkan pada bagian samping bangunan terdapat penambahan ruang privat yang berfungsi sebagai kamar tidur.

\section{Perluasan dan/atau penambahan secara horisontal.}

Bangunan mengalami perubahan secara horisontal dengan adanya penambahan dan perluasan beberapa ruang dengan menambahkan konstruksi baru. Pembangunan konstruksi baru dilakukan pada saat pengantian material bangunan lama dengan baru dan melakukan sekaligus penambahan konstruksi untuk penambahan ruang. Pada sampel perubahan ringan, bangunan inti tidak 
mengalami perubahan material selain pada sisi luar bangunan yang mengalami penambahan konstruksi sebagai perkuatan.

\section{Perluasan dan/atau penambahan secara vertikal.}

Pembangunan konstruksi bangunan secara vertikal dengan menambahkan konstruksi baru merupakan cara dalam melakukan adaptasi bangunan. Penambahan konstruksi secara vertikal paling banyak ditemukan pada sampel perubahan sedang 1 unit rumah dan 10 unit rumah perubahan total. Berdasarkan hasil observasi lapangan, penambahan atau pembuatan konstruksi baru berlangsung pada periode 1990-2000-an. Pada periode tersebut pembangunan secara vertikal karena adanya penambahan anggota keluarga atau kepentingan usaha (kos-kosan) sehingga memerlukan ruang tidur. Sampel yang mengalami perubahan total dalam pembangunan konstruksi baru secara vertikal ada yang dilakukan bertahap maupun total.

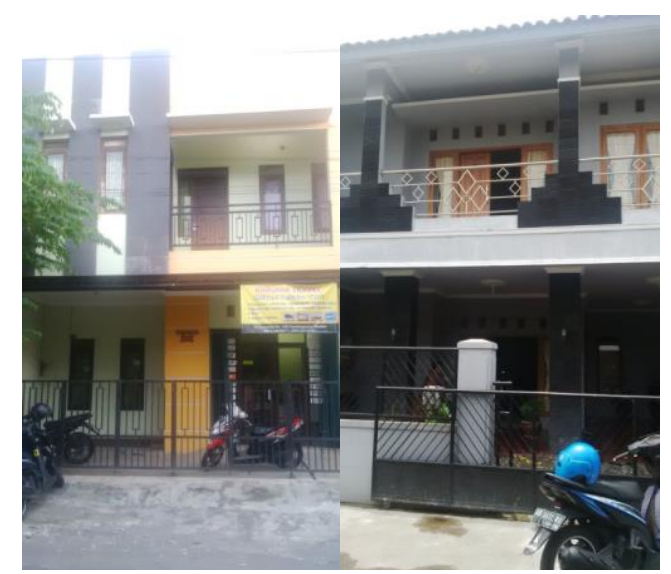

Gambar 10. Sampel Konstruksi Banguan secara Vertikal di Perumnas Condong Catur

(Sumber: Observasi Lapangan, 2015)

Berdasarkan hasil analisa tersebut maka strategi yang terjadi di Perumnas Condongcatur dapat diuraikan seperti dibawah ini.

\section{Perubahan Perabotan atau Furniture (Adjustable)}

Strategi perubahan perabotan atau furniture (adjustable) dalam adaptasi bangunan berkaitan dengan perubahan tatanan perabotan atau furniture dalam rumah. Karakteristik strategi perubahan perabotan atau furniture (adjustable) yang dikemukakan oleh Schmidt yaitu tipe perabotan, hubungan koordinat, modul, sistem sambungan, easy interface, elemen bongkar pasang, mudah disimpan dan non-fixed elemen.

Hasil temuan menunjukkan bahwa penambahan perabotan baru dapat dikategorikan sebagai strategi penataaan perabotan atau furniture (adjustable). Tipe perabotan yang dinyatakan oleh Schmidt belum menjelaskan secara detail, sedangkan pada hasil temuan terdapat penambahan perabotan baru yang dapat merubah penataan. Hal tersebut menyebabkan penambahan kategori baru dalam teori tersebut. Periode terjadinya penataan perabotan atau furniture karena adanya penambahan perabotan baru terjadi pada kurun waktu 10 tahun terakhir atau sekitar periode 1998-2007 dan 2008-sekarang. Hal ini berkaitan dengan adanya kebutuhan penghuni dan perabotan lama yang telah mengalami kerusakan.

\section{Perubahan Tatanan Ruang (Versatile)}

Strategi perubahan tatanan ruang (versatile) merupakan strategi adaptasi bangunan yang berkaitan dengan tatanan spasial ruang. Tatanan spasial dipengaruhi oleh penggunaan ruang yang digunakan secara multifungsi. Karakteristik strategi ini antara lain portabel, unit modular, easy connections, unit yang dapat disusun dan mudah untuk dibongkar. Strategi perubahan tatanan ruang (versatile) pada teori Schmidt menekankan pada perubahan elemen ruang sesuai dengan kebutuhan pengguna.

Hasil temuan penataan ulang layout ruang untuk kegiatan komunitas sosial dan keluarga dapat dikategorikan sebagai strategi perubahan tatanan ruang (versatile). Tipe komponen yang dinyatakan oleh Schmidt belum menjelaskan perabotan yang mudah dilipat ataupun dipindahkan. Hal tersebut berkaitan dengan hasil temuan perabotan yang mudah dilipat dengan menggunakan tikar dan perabotan yang dipindahkan dengan menggunakan perabotan yang terdapat diruang lain. Periode terjadinya perubahan tatanan ruang (versatile) menurut teori Brands Layer terjadi pada harian ataupun bulanan. Hasil temuan menunjukkan adanya periode dominan terjadinya strategi ini pada tahun 1988-1997.

\section{Perubahan Performance Komponen (Refitable)}

Strategi perubahan performance komponen (refitable) merupakan penggunaan komponen 
pada bangunan yang dapat mempengaruhi bentuk ruang sehingga dapat memberikan tampilan yang berbeda. Karakteristik strategi ini berkaitan dengan elemen fisik komponen pada bangunan, yaitu partisi yang dapat dipindahkan, komponen yang dapat dilipat dan sesuatu yang dapat mengubah tempat.

Hasil temuan menunjukkan bahwa terdapat komponen yang dapat digeser. Komponen tersebut digunakan pada sampel rumah di Perumnas Condongcatur sebagai pembatas antar ruang dalam dan luar. Periode terjadinya perubahan performance komponen (refitable) menurut teori Brands Layer terjadi pada jangka waktu 7 tahun sedangkan hasil temuan menunjukkan periode dominan pada tahun 1988-1997.

\section{Perubahan Fungsi (Convertible)}

Strategi perubahan fungsi (convertible) berkaitan dengan adanya perubahan fungsi bangunan yang di akibatkan oleh penggunaan ruang yang digunakan bersama dengan fungsi yang berbeda. Strategi ini berbeda dengan strategi perubahan tatanan ruang (versatile) yang berkaitan dengan tatanan spasial. Karakteristik strategi ini adalah luas ruang, material terbarukan, dan mudah dilipat. Adaptable futures menambahkan karakteristik dalam strategi perubahan fungsi (convertible) yaitu ruang multifungsi dan kapasitas pelayanan.

Pada hasil temuan perubahan fungsi (convertible) bahwa penggunaan ruang bersama untuk acara komunitas dan keluarga dan perubahan dan/atau penambahan fungsi bangunan. Perubahan fungsi bangunan mempengaruhi perubahan fungsi ruang yang terdapat didalam bangunan dengan adanya perubahan dan/atau penambahan. Hal ini dapat dipengaruhi oleh adanya kebutuhan pengguna yang mengakibatkan perubahan pada ruang dan bangunan. Fungsi ruang awal yang mempunyai pembagian zonasi sesuai dengan penggunaan ruang kemudian berubah menjadi zonasi dengan fungsi lain. Periode strategi perubahan fungsi (convertible) berdasarkan teori berlangsung setelah 15 tahun, sedangkan pada hasil temuan dominasi berlangsung pada awal periode tahun 19781987.

\section{Perubahan Ukuran (Scalable)}

Strategi perubahan ukuran (scalable) adalah perubahan bangunan karena adanya perluasan bangunan dengan penambahan konstruksi baru. Karakteristik strategi ini adalah penggunaan material daur ulang dan penggunaan kembali bagian bangunan yang dapat digunakan. Adaptable futures menambahkan karakteristik strategi scalable adalah unit modular, penggabungan/pemisahan ruang dan penambahan struktur.

Hasil temuan perubahan ukuran (scalable) di Perumnas terdapat dua perubahan dalam penambahan struktur yaitu secara horisontal dan vertikal. Penambahan struktur secara horisontal dilakukan dengan memaksimalkan lahan yang ada. Penambahan struktur juga terjadi pada perluasan secara vertikal pada bangunan eksisting. Periode strategi perubahan ukuran (scalable) berdasarkan teori berlangsung setelah 15 tahun, sedangkan pada hasil temuan dominasi berlangsung pada tahun 1998-2007.

\section{Perubahan Tatanan Layout Perabotan}

Strategi perubahan tatanan layout perabotan tidak termasuk kedalam lima strategi yang dinyatakan oleh Schmidt. Strategi ini membahas tentang perubahan tatanan layout perabotan karena adanya penambahan, pemindahan dan perluasan ruang. Ruang yang bertambah, berpindah dan bertambah luas akan mempengaruhi penataan layout perabotan secara keseluruhan. Strategi perubahan tatanan layout perabotan tidak termasuk dalam strategi perubahan perabotan atau furniture (adjustable). Hal ini disebabkan karena perubahan perabotan menekankan pada elemen fisik barang yang mempengaruhi perubahan tampilan pada ruang, sedangkan pada strategi ini ruang mempengaruhi penataan perabotan. Strategi perubahan tatanan layout perabotan juga berbeda dengan strategi perubahan tatanan ruang (versatile) yang berkaitan dengan adanya perubahan layout tatanan perabotan pada ruang yang digunakan sebagai tempat kegiatan bersama.

Karakteristik strategi perubahan tatanan layout perabotan adalah perluasan ruang, pemindahan ruang, dan pertambahan ruang. Periode berlangsungnya strategi perubahan tatanan layout perabotan berdasarkan perubahan yang berkaitan dengan adanya perubahan dan perluasan ruang. Periode dominasi strategi perubahan tatanan layout perabotan pada tahun 1988-1997. Strategi perubahan tatanan layout perabotan tidak termasuk kedalam lima strategi yang dinyatakan oleh Schmidt. Strategi ini membahas tentang perubahan tatanan layout 
perabotan karena adanya penambahan, pemindahan dan perluasan ruang. Ruang yang bertambah, berpindah dan bertambah luas akan mempengaruhi penataan layout perabotan secara keseluruhan. Strategi perubahan tatanan layout perabotan tidak termasuk dalam strategi perubahan perabotan atau furniture (adjustable). Hal ini disebabkan karena perubahan perabotan menekankan pada elemen fisik barang yang mempengaruhi perubahan tampilan pada ruang, sedangkan pada strategi ini ruang mempengaruhi penataan perabotan. Strategi perubahan tatanan layout perabotan juga berbeda dengan strategi perubahan tatanan ruang (versatile) yang berkaitan dengan adanya perubahan layout tatanan perabotan pada ruang yang digunakan sebagai tempat kegiatan bersama.

Karakteristik strategi perubahan tatanan layout perabotan adalah perluasan ruang,pemindahan ruang, dan pertambahan ruang. Periode berlangsungnya strategi perubahan tatanan layout perabotan berdasarkan perubahan yang berkaitan dengan adanya perubahan dan perluasan ruang. Periode dominasi strategi perubahan tatanan layout perabotan pada tahun 19881997.

\section{KESIMPULAN}

Adaptasi bangunan adalah kapasitas bangunan untuk menampung secara efektif dalam mengakomodasi tuntutan yang berkembang dari konteks, sehingga dapat digunakan secara maksimal. Perumnas Condongcatur sebagai perumahan pertama mengalami banyak perubahan pada bangunan. Perubahan tersebut dipengaruhi oleh adanya perkembangan kawasan pada lingkungan sekitar. Kawasan yang pada awalnya hanya area permukiman kemudian berkembang menjadi kawasan jasa dan komersial yang mempengaruhi perubahan pada bangunan permukiman. Hasil penelitian yang telah dilakukan bahwa terdapat enam strategi yang terdapat di Perumnas Condongcatur. Teori strategi yang dinyatakan oleh Schmidt terdiri dari lima strategi dan satu strategi movable. Berdasarkan hasil temuan terdapat penambahan pada strategi adaptasi bangunan dan karakteristik pada setiap strategi yang dinyatakan oleh Schmidt. Strategi yang terdapat di Perumnas Condongcatur antara lain:

1. Perubahan perabotan atau furniture (adjustable) dengan penambahan karakteristik perabotan baru;
2. Perubahan tatanan ruang (versatile) dengan penambahan karakteristik perabotan yang mudah dipindahkan dan perabotan yang dilipat;

3. Perubahan performance komponen (refitable) dengan penambahan karakteristik komponen yang dapat digeser;

4. Perubahan fungsi (convertible) dengan penambahan karakteristik perubahan dan/atau penambahan ruang;

5. Perubahan ukuran (scalable) dengan adanya pembagian penambahan struktur menjadi horisontal dan vertikal; dan

6. Perubahan tatanan layout perabotan. Strategi ini berkaitan dengan adanya perubahan tatanan layout perabotan karena adanya penambahan, pemindahan dan perluasan ruang.

\section{DAFTAR PUSTAKA}

[1] Schmidt III, R., Deamer, J., dan Austin, S. 2011. Understanding Adaptability Through Layer Dependencies. International Conference on Engineering Design, ICED11. Technical University of Denmark.

[2] Schmidt III, R., Eguchi, T., Austin, S., dan Gibb, Alistair. 2010b. What is The Meaning of Adaptability in The Building Industry?. Loughborough University. United Kingdom.

[3] http://adaptablefutures.com/ourwork/toolkit/. diakses 14 Desember 2014

[4] Brand, S. 1994. How Buildings Learn. New York: Viking.

[5] Tjahyono, YP. Suhodo. 2004. PERUMAHAN BAGI MASYARAKAT BERPENGHASILAN MENENGAH KE BAWAH DI PERKOTAAN

[6] Perumnas. 2013. Perumnas, Hingga Kini Perannya Tak Tergantikan. Rumah Kita Buletin Perumnas. Pp. 8-9

[7] Perumnas.co.id. 2015. Sejarah Perumnas. http://www.perumnas.co.id/sejarahperumnas/ 